\title{
CHICAGO
}

KREISMAN WORKING PAPER ON HOUSING LAW AND POLICY NO. 22

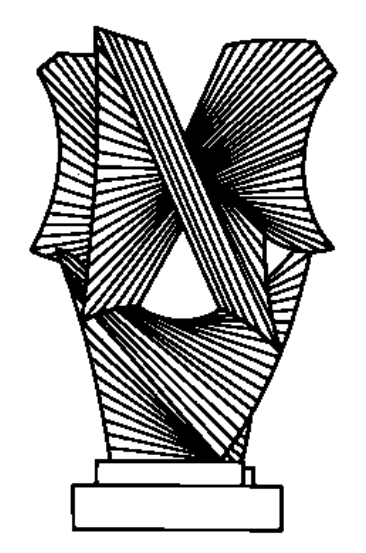

\section{INVESTORS EFFECT ON HOUSEHOLD REAL ESTATE AFFORDABILITY}

\author{
Sebastien Gay
}

\author{
THE LAW SCHOOL \\ THE UNIVERSITY OF CHICAGO
}

May 2015

This paper can be downloaded without charge at the Kreisman Working Papers Series in Housing Law and Policy: http://chicagounbound.uchicago.edu/housing_law_and_policy_wp/ and The Social Science Research Network Electronic Paper Collection. 


\title{
Investors Effect on Household Real Estate Affordability
}

\author{
Sebastien Gay*
}

May 1, 2015

\begin{abstract}
We examine whether the recent behavior of real estate investors had an effect on housing affordability between 2007 and 2014. We analyze investors' purchasing and selling behavior and study their spillover effects on the affordability of the local real estate market where they invest. We find that large portfolio investors decrease the affordability in neighborhoods, reselling a property bought at the 37 th percentile at the 70 th percentile of the market. We also find that in order to maximize yield, investors tend to invest in poorer neighborhoods, leading to a decrease in affordability for lower income population wanting to buy a property in these areas.

Keywords: Affordability, Investors, Housing, Resale, Mortgages, Signal, Valuation.

JEL Classification: O18, R00, R33.
\end{abstract}

*Department of Economics, University of Chicago, 1126 E. 59th Street, Chicago IL, 60637 USA. All mistakes are my own. E-mail address: sgay@uchicago.edu 


\section{Introduction}

Housing and economic recovery has been widely debated in the past few years. ${ }^{1}$ The current recovery has been quite slow but home sales seem to have actually increased contrary to the current trend of increased number of renters and decreasing home ownership. Such a trend may be explained by the fact that investors have done a large portion of the buying over the past five years. Real estate investment has historically been a source of fast and strong returns for investors. $^{2}$ In this paper, we explore the effect of investors on the real estate market on the affordability of homes.

The affordability measure can be simply defined by how much real estate household can afford with their income. Simply put, households need to spend some of their income on their rent or their mortgage and might not have a large enough amount left for other necessities like food or other fundamental consumptions. Unfortunately, the academic literature does not have a housing affordability standard measure (Thalmann (2003), Bertaud (2009)). It is usually measured by the cost burden (ratio of housing cost to household income) (Kutty (2005)) considering the ratio of current median or mean market value of the standard housing unit to the median or mean disposable income of the household (Chen et al. (2010)). The usual thresholds considered are $25 \%$, $30 \%, 40 \%$, and $50 \%$ price-to-income ratio. Households exceeding those ratios are considered households with a housing affordability problem (Kutty (2005)). In particular, the U.S Department of Housing and Urban Development (HUD) defines unaffordability as a more than 30 percent of income. This ratio suffers from several shortcomings: a lack of integration of households' preferences for different housing qualities (Bogdon and Can (1997), Kutty (2005)); a potentially large variation amongst households (Stone (2006)) and within acceptable percentages left for non-housing expenditures. Therefore a residual income approach, taking into account household composition and size is usually preferred (Stone (2006)). Hulse et al. (2010) consider housing affordability as the difference between housing costs and the residual income after housing costs. This measure, albeit more accurate, may be difficult to evaluate as standards for adequacy might vary within households and neighborhoods. Moreover, Leishman and Rowley (2012) explain that a real measure of affordability needs to control for the quantity and quality of the homes available, the households' housing demand and requirements, and location or neighborhood effects.

This paper contributes to the academic literature by analyzing the effect of investors' presence on affordability. More specifically, we argue that investors tend to increase housing quality and prices in neighborhoods, which in turn raises the housing costs for lower income households. Using a novel dataset over the period 2008-2014, we find that investors get an average return of $100.4 \%$,

\footnotetext{
${ }^{1}$ Bracke (2013) shows that in OECD countries upturns and downturns have some duration dependence and that house prices are cyclical.

${ }^{2}$ See, for example, Do investor home sales mask a sick housing market?, Housing Wire, February 6, 2014. http://www.housingwire.com/articles/28875-do-investor-home-sales-maska-sick-housing-market. Last accessed 04/20/2015.
} 
due to the fact that most investors decide to rehab or upgrade homes, compared to $35.8 \%$ for non-rehabbed homes. ${ }^{3}$ This translates into an inflated sell price for homes in neighborhoods where investors have placed their bets, leading to lower affordability for middle-class families.

\section{Data}

We construct a novel dataset using different sources. We first get investors data from Core Logic Investor datasest, which comprises investors and the price and coordinates of the properties they bought. The data contains names and addresses of the businesses but does not provide a full address of the properties. In order to match the properties with the investors, we use the Midwest Real Estate Data (MRED) from 2007-2014, the data listing aggregator from the Chicago area multiple listing service, usually known as MLS. ${ }^{4}$ It contains information about each property on the market with the listing date, sale date, list and sale prices, and all of the home characteristics. It also contains pictures and descriptions from the real estate broker. We determine the investor activity by matching the tax number of each of the properties in the Core Logic sample with the tax number for each home address in the MRED dataset. We manage to match $78 \%$ of investor properties. Some of the investor properties were matched multiple times on the MLS (as the property experienced multiple transactions - sometimes before the investor transaction; sometimes after). We will use these repeated sales as a robustness check for our results. We correct for some inconsistencies with the dates of acquisition between MLS and Core Logic dataset as the "closed date" from the MLS dataset and the "acquisition date" in the Core Logic dataset may not match. We only consider observations with both dates within a week of each other to avoid possible quick turnarounds. We collected data on all the matched homes, focusing on the critical information typically used by a potential buyer: size (in square feet), number of bedrooms, number of bathrooms, year built, buyer and seller realtor names, past sale history, school rating, as well as all realtor-uploaded photos and the realtor's text remark. Additionally, we obtain post-sale information such as the final sale date and final price. We get the public school ranking from the School Digger website and match school boundaries to properties or neighborhoods. We measure distances to the downtown area or the nearest school. We calculate the coordinates of the schools and the downtown area and measure the distance between those and each property in our sample. The vacancy rates, auction rates and foreclosure rates come from the U.S. Department of Housing and Urban Development (HUD). We use the median income data from the Census Bureau with the ACS 5 Year Surveys (2007-2011, 2008-2012, 2009-2013). ${ }^{5}$ The

\footnotetext{
${ }^{3}$ Those yields are measured in gross terms, without controlling for rehabilitation or upgrade costs. If we use an average measure of costs, the yield is $52.5 \%$.

${ }^{4}$ The choice of the time period is central to our analysis as we wanted to make sure to avoid the real estate bubble. Most non-institutional investors have disappeared around 2007 after large monetary losses. Our study focuses on the beginning of the new investment cycle.

${ }^{5}$ We also use the IRS and BEA files as a robustness check.
} 
turnover rates are calculated from MRED MLS, HUD Aggregated USPS Administrative Data On Address Vacancies. We also use some measures of increase in inequalities with the Census and the American Community Survey. Following Choi and Greene (2015) we control for disparities within a community like labor force participation, racial concentration, industrial composition and residential mobility.

We also build a rental market dataset. During times when resale prices are lower, investors rent their properties rather than sell at a lower price. We match the rental properties as follows. We consider all investor sales matched with Core Logic and MLS as defined above and match the data that has MLS purchase and sales prices based on location and transaction. We then match the investor sales with rental listings using both addresses and coordinates of the properties, as the MLS did not provide tax numbers for rental listings. The matching is done at the decimal level, which corresponds roughly to a 15-meter radius. We then ensure that the street number and the address are matched correctly. We match successfully 2,329 properties with rental listing, i.e. around $30 \%$ of the total matched observations. This is mainly due to the fact that we only measure broker-listed rental properties. Some other properties could also be listed on a rental market that does not rely on MLS, like Craigslist or direct rentals.

We assemble a dataset for 2014 of home sales with mortgage, buyer and seller information data. We go through each listing on our sale matched dataset in 2014 and match by hand the data on buyer and seller to follow the properties buyers and sellers, using a Core Logic data set connected to the MLS. From this data source, we collected the identity of the buyer and whether the buyer took out a mortgage - detailing the type of loan, the rate, and term length. ${ }^{6}$

\section{Investors Home Buying Trends: Where and What Do They Buy?}

The period 2007-2014 considered for this paper has witnessed a huge change in real estate activity. We can see on Figure 1 that the average sales price was on the decline over the period 2007-2012. Since 2012, home prices have rebounded in value. A similar pattern of investor activity can be seen on Figure 2. Investors have had an increasing presence on the market. They only represented around $4 \%$ of all of the total home sales activity until 2012. After 2012, investor activity peaked at $7 \%$. Figure 1 shows more specifically the investors purchase activity for the Chicago metropolitan area. In Figure 1 we divide more specifically investors into two types of firms: (1) corporate institutional institutions, like Blackstone and American Homes 4 Rent, and (2) non-institutional investors, or local investors that usually hold a portfolio of less than ten properties, like JC real estate. We can see that in 2012-2013 there was a huge increase in institu-

\footnotetext{
${ }^{6}$ This process also validated the initial matching algorithm as we were able to confirm the seller entity and the historical transactions on the property.
} 
tional investors' activity, quadruple the amount of total residential transactions compared to 2011. A similar pattern exists for non-institutional investors, with the slight change that those investors were buying more properties during the recession periods. We find that institutional investors have more than ten properties on average, whereas non-institutional ones hold less than ten.

Figure 3 also shows the investors activity in the Chicago Metropolitan area. We notice that there is a large increase in investor activity in zip codes with more than $10 \%$ or $20 \%$ activity over time. ${ }^{7}$

We present in Figure 4 and Figure 5 heat maps of investors' activity and median income. We notice that investors avoid high income areas, as any potential marginal return over time is small. Based on these maps, we find that investors flood lower area income in the south corner of the map, with lower income and more growth potential. Nonetheless we see that investors usually spread out, which suggests that they try to use their local expertise to pick neighborhoods in which they invest.

Table 1 presents summary statistics of the key variables for our study, using both institutional and non-institutional investors. Non-institutional investors tend to hold more properties overall. They are also more invested in the local market ( $88 \%$ vs. $59.7 \%$ ). Their premium is usually higher than for institutional investors. Institutional investors also hold fewer properties but tend to have a lot of investment outside of the state. It is an interesting result, as contrary to the non-institutional investors, they could acquire properties using their subsidiaries in other states.

More interestingly, non-institutional investors tend to invest closer to their headquarters, as they have a local experience and knowledge of the market (i.e. closer to their headquarters), compared to institutional investors. Table 2 summarizes the results of this measure of the distance between acquired properties and buyers' headquarters. We geocode the addresses of the headquarters of each of the investment firms in our sample and measure the distance between any property investors buy and their respective headquarters. We find that the majority of non-institutional investors tend to acquire properties close to their headquarters: more than $70 \%$ are within 10 miles, with $50 \%$ less than 5 miles away. On the contrary, institutional investors acquire only $20 \%$ of their properties within 5 miles of their location. Overall, institutional investors tend to diversify their acquisition portfolios with respect to location. This seems to emphasize the fact that non-institutional investors have more local knowledge. It also implies that institutional investors in real estate behave like stock buyers, mixing their portfolios in terms of neighborhoods and prices.

These patterns will be important to compare when developing some of our results. A surprising and telling result shows that Blackstone buys in higher proportions away from where non-institutional investors usually buy. Most of

\footnotetext{
${ }^{7}$ For all figures, the drop in 2014 is only due to the fact that the first quarter in 2014 has been fairly low in investments (as are usually winters) and the investors activity for that year has been the quarter number multiplied by 4 . As soon as the data for the full year becomes available we will include it in the sample. Most results are calculated both with and without the 2014 data.
} 
their acquisitions are in less affluent areas like the south suburbs of Chicago. Figure 6 shows how Blackstone's buying behavior compares to its competitors. We notice that Blackstone buys a lot of properties in the south east portion of Illinois, presumably because it is betting on the development of this area, mainly in Oak Lawn and portions of the city of Chicago.

\section{Investors Returns on Sold Properties}

We build a dataset of matched properties to see whether the non-institutional or institutional investors gain the most from their investments. In order to follow properties over time, we match the Core Logic investor data to the MLS sales data in the Chicago Metro Area. We only consider the Chicago Metro Area to avoid having too many changes in the considered area. For example, suburbs further away from Chicago might have characteristics that are different from those closer to the city of Chicago. Table 3 presents the results of the matching. Given that the datasets are presented differently, we consider a match when the list date is before the acquisition date and the closed date is after the acquisition date. Alternatively, if a list date comes after the acquisition date, it would almost have to guarantee a sale, likely a quick sale. Table 3 reports the results of the matching. To be conservative, we consider only perfect matches, explaining the decrease in the number of observations in our sample. Overall we have 641 matched properties that we can follow over time, 534 for noninstitutional and 107 for institutional investors. We show in Figure 6 a map of the investor activity data matched through our process. We divide the groups into Blackstone, our main institutional investor, other institutional investors, and the smaller investors. We notice that the match data spans the entire state and that institutional and non-institutional investors buy mostly in similar areas.

Table 4 presents the premium calculation for non-institutional and institutional investors using the matched dataset as well as the average turnover. We notice that on average non-institutional investors sell the properties faster than their institutional counterparts, albeit also holding on to it for around 2 years over the period 2007-2014. This may be due to the 2008 recession or to the fact that most properties are bought in lower income neighborhoods, where investors expect a turnaround, and spent time renovating or remodeling them. We tested both assumptions. The recession had a small effect on the time on the market, but most properties in the matched dataset were bought in the lower price time period after 2009. The second proposition was tested as follows: we considered the descriptions of the properties, prior and post investor's involvement. Using the MLS data, we used a series of words that would imply that the homes were upgraded. Table 5 presents all the words used in the analysis. ${ }^{8}$ Table 6 presents the results of the analysis. We find that $60 \%$ of the matched sample has some

\footnotetext{
${ }^{8}$ The word used where picked from a real estate disctionary on rehabilitation and upgrades of homes. The list presented in Table 5 will be updated based on another list from construction and rehabilitation companies.
} 
form of renovation within their MLS description. We reviewed the descriptions and considered a conservative approach, considering as no match for renovation any unclear description, even if some upgrades could be infered from the listing itself. Using the stratified approach of levels of renovations, we find in Table 7 that the premium is greatly derived from the renovations of the properties. On the matched data, the average sold premium is $112.4 \%$ for renovated properties, compared to only $35.8 \%$ on average for non-renovated properties. ${ }^{9}$ We also find that it seems harder to resale a property that did not have any renovation $(1,070$ days on average) compared to one that has been renovated (483 days).

\section{Investors Affordability Effect}

We consider how investors change sales prices within a given neighborhood as a result of their presence and investment behavior. More specifically we estimate the equation:

$$
\log \left(p_{i t}\right)=\alpha+\beta X_{i t}+\gamma I_{i t}
$$

where $p_{i t}$ is the sales price of the home, $X_{i t}$ corresponds to all controls on the home and community, and $I_{i t}$ is a dummy variable corresponding to an investor purchase. We control for year fixed effects and proximity to downtown. We also want to check whether any effect of auctioned homes could change the results. In order to fully control for investors' presence within a community we include the investor rate within that community. It is defined as the ratio of the number of properties bought by investors over the total amount of properties sold in the year prior to the closing date of a given property. ${ }^{10}$

Table 8 presents the results. We find that overall there is a significantly positive effect on price, albeit small for investors purchasing activity. This might be due to the fact that investors are expected to invest in the property they buy to make the neighborhood better or the intrinsic fact that investors tend to have large premium, leading real estate brokers to anticipate higher sale prices in the future. Investor are also less likely to negociate prices down as they buy multiple properties to diversify their risks. ${ }^{11}$

In order to compare how the investors' presence affects a community, we consider a similar regression, controlling for sales and purchases by different types of investors. Table 9 shows the results of the regression of the sales prices in a given neighborhood as a function of investors overall activity, selling and buying, controlling for all of the local community, property characteristics

\footnotetext{
${ }^{9}$ As mentioned earlier, the average sold premium becomes $52.5 \%$ considering the average cost of renovation. Note that we present those results in the raw/gross premium form as costs may differ per renovated home. It may be more complicated to have a clear comparison.

${ }^{10}$ Note that investors mostly invest in lower income neighborhoods. It is consistent with a potentially higher premium when homes sell. Investors' presence affects the different neighborhoods pricing themselves for purchases and sales of homes.

${ }^{11}$ From interviews with investors in real estate, we found out that most of them do not actually visit the homes they will eventually make an offer on.
} 
and year fixed effects. ${ }^{12}$ We find that on average there is a positive effect on homes prices of both the sales and purchases of properties by investors. Overall, institutional investors have a larger effect than the non-institutional ones. It is consistent with the fact that investors overpay for homes on average when they purchase them and get a higher return when they sell them. We also notice that homes sold by investors tend to sell at a higher price, more than 10 times the larger price paid by investors at time of buying. This comparison validates the higher purchase price of a property initially as investors know that they will then have a larger yield at time of resale.

Investors seem to buy properties at a higher price within a neighborhood. We try to measure the determinants of investors' home purchasing decision. We compare how purchase price might change considering the portfolio count for each investor, whether the investor is institutional or not, the auction effect, distance to their headquarters. We also control for local community, property characteristics, year fixed effects, proximity to the city center, and the investor rate in the neighborhood. Table 10 reports the results. Overall the coefficients are robust to the choice of specification and we find that institutions seem to buy at a lower price than non-institutional ones. Properties bought at an auction have an expected price that is lower on average. The distance seems to also play a role as investors pay on average a higher price a home closer to their headquarters. This could be related to the fact that investors might feel more comfortable with their knowledge of the prices in their area. In particular, noninstitutional investors might be more willing to pay a higher price to buy a property closer to their headquarters. They also know the type of competition they may face within their close neighborhood.

We estimate how the premium is impacted by neighborhood characteristics. Investors tend to invest in lower income neighborhoods, but if schools and income measures improve over time, the premium may become larger. Table 11 presents the results. We notice that the median income has a negative effect on the resale premium. It is consistent with the lower probability of investors buying properties in higher income areas. We also find that the better the school rank, the larger the premium. It is a consistent result with prospective buyers focusing on neighborhoods with good quality schools. We also find that vacancy rates have a negative effect on the premium. Interestingly, the foreclosure rate in the neighborhood seems to have a positive effect on the premium. It may be due to the fact that investors actually buy a portion of the foreclosed homes and rehabilitate them.

We measure the impact of effect of investors' presence on nearby properties. We consider properties that are close enough to the investor-owned property, within one mile. We try to find the effect within cluster of high investors presence, where we identify hotspots where lots of investors have purchased homes within an area very quickly. Table 12 presents the results of a regression of the effect on sales prices of properties one mile nearby an investor cluster. We find

\footnotetext{
${ }^{12}$ Similarly to the previous model, we control for auction and investor rate within a neighborhood.
} 
that a year after the cluster, homes are expected to be on average more expensive. We also find that there is a small and significant negative effect on prices of homes within the cluster. This effect is somewhat controlled for potentially auction rates.

Table 13 goes into details on what are the main characteristics that investor purchasing would have on the local real estate market. We consider the effect on investor activity per zip as a function of foreclosure rate, income, school quality, vacancy rates, and location within city limits. We find that overall investors tend to invest in higher foreclosure area, with lower income and low school quality, but with low vacancy rates. Locations at the periphery of the city are also preferred. This is consistent with the development of areas around the city of Chicago where more potential for high returns could be seen. It is also consistent with the heat maps from Figure 4 and Figure 5.

An important impact of investors' presence in a neighborhood is the role in price setting in a neighborhood. We use a measure of affordability based on people's income within a neighborhood and investment or mortgage companies as a percentage of income. Given lower interest rates on mortgages, more potential buyers should be able to have access to credit to buy a property. We find that interestingly investors' presence leads to a decrease in affordability of home prices and rent in a neighborhood.

We also measure how the investors, in particular Blackstone, change the affordability of real estate in neighborhoods in which they acquire properties. We consider the level of affordability based on different ratios of income to rent. More specifically, we consider $20 \%, 30 \%$, and $40 \%$ of the income. We think of affordability as the ability of renters to be able to buy a home within a particular area, using a portion of their income. We find that controlling for area controls and property controls, that Blackstone usually decreases potential buyers' ability to afford a home. Table 14 reports the result for using the $20 \%$ percent rent to income ratio, Table 15 for the $30 \%$ percent rent-to-income ratio, and Table 16 for the $40 \%$ rent-to-income ratio. All of those tables also account for potential robustness checks. Table 17 summarizes the results for the full specification. We find that Blackstone adds an extra level of decreased affordability when compared to other investors. This effect tends to disappear when we consider the 40 th percentile (with only a $9 \%$ increase in the price potential buyers need to add to other properties sold by institutional investors) but it adds more than $18 \%$ to the institutional investors price.

We consider different measures of yield for investors. We use first a yield based on purchase price. The issue with it is that the results could be misleading considering that institutional investors invested more recently compared to smaller investors that purchased their properties earlier. We control the yield using the FHFA index for the Chicago Metro Area. It has the nice property that it is available for more than 10 years back but is only at a larger area than a zip code control. Another way to control for it is using the average MLS sales within the year of the sale. We construct a distribution of the homes sold around an investor purchase and we compared that particular distribution to the properties sold at the time the property the investor is selling. Table 18 
presents the results using FHFA index. Table 19 uses zip code-level transactions. The results offer the perspective that on average institutional buyers get an adjusted acquisition price lower than their non-institutional counterparts. The overall average is actually similar for both normalizations.

The results in Table 18 were used in the regression results presented in Table 17. Even though Blackstone's home price is much lower than the other investors - the affordability of these houses is much lower. This seems to indicate that Blackstone is comparatively overcharging for rent and that their pricing is less affordable to the community.

Using a sample of home matched in 2014 using buyers and sellers names, we measure how investor-owned home prices and mortgages differ depending on whether another investor or a regular buyer acquires it. We identified "investor buyers" as those with names like "LLC or Inc.". The complete list is shown in Table 26. In total, Table 27 indicates that investors tend to sell $7.8 \%$ homes to other investors. Table 28 indicates investors sell $14.0 \%$ of their properties to cash buyers. This usually leads to an increase in prices within the neighborhood, even for non-remodeled homes. It may be due to the access to cheap credit and that some investors want to build a portfolio of properties while some other investors welcome the sale.

In a way, the fact that the property was bought by an investor seems to give the buyer-investor a strong signal that the property and the neighborhood have an upside. Table 31 details a probit regression to estimate the likelihood of whether the property was sold back to an investor. Investors seem to buy properties from investors with large portfolios, as well as properties that are more affordable to the community. However, on the whole, investors seem to buy in less desirable areas where the high school rank is comparatively lower. The result also shows that investors rarely buy from investors who own multiple properties in an area. This may be because the original selling investor has more knowledge of the neighborhood and is confident to sell back to the community for a better profit.

We also look in detail at the average rank of the home that is purchased by the investor. Table 29 indicates that at the time of purchase, the property is valued at around the 37 th percentile with respect to what is being sold on the market. When the investor sells the property, it is sold around the 70th percentile. This is due to a combination of the property gaining value with remodeling or the property possibly being overvalued by a new buyer.

In a sense, because investors are purchasing lower value houses, they are removing available housing stock for lower income households in the area. When an institutional investor (an investor with more than 10 properties) sells a property back to the consumer, it appears that they sell the property at a comparatively unaffordable rate. Even though Table 30 seems to indicate that both types of properties are comparable at an aggregate affordability level, when controlling for property characteristics and local community fixed effects, Table 31 indicates that institutional investors are selling properties at unaffordable rates. This seems to indicate that institutional investors are over-charging for properties lower quality properties, burdening lower income individuals. 
We look in detail at the types of mortgages that individuals take out when purchasing investor owned homes. We considered the mortgage and transaction history on the property individually through the Core Logic database. We estimate the monthly ownership cost that is a combination of tax and monthly mortgage payments. We use the tax on the property from the MLS listing.

The equation for the monthly ownership cost is:

$$
P=L \frac{r(1+r) n}{(1+r) n-1}
$$

where $L$ is the loan amount, $r$ is monthly rate, and $n$ is the number of months. ${ }^{13}$ We approximated some of the values when missing using the sold price of the house as the default principal, the national average default rate for 2014 and 30 years for time of mortgage, as it is the average number of years.

We find that a substantially higher number of individuals take out FHA loans for low income individuals who cannot afford a down payment on the purchased home when purchasing from investors when compared to the average type of loan available. It may be that a higher concentration of individuals buying from investors take out FHA loans because the properties are more unaffordable for them. Table 21 and Table 22 indicates that the share of the individuals buying investor properties is much higher than the national average for 2014. Table 25 indicates that individuals buying homes at low to mid-level price cannot afford a large downpayment (between 4 and 10\%). It seems to indicate that the buyers do not have the appropriate assets to purchase the home.

\section{Interpretation and Discussion}

Overall investors tend to have a very large return on their investments. This may be due to the period of analysis as the market has bottomed out in 2009 . Nonetheless, the overall returns have been around $14 \%$ overall for non-renovated homes, and more than $90 \%$ for renovated homes. It seems important to note that homes have overall been held for around a year for renovated homes and sold at a high premium. Non-renovated homes have been in the investors portfolio for more than 3 years on average. It might seem to imply that investors might have either tried to wait for the market to rebound, or see if the development of the area would happen, or perhaps they rented the home for a few years to ensure a cash-flow for a period of time when the real estate market was not providing large returns. Another interesting pattern for investors is the fact that they tend to invest in neighborhoods with lower income and less developments. The advantage is that if those neighborhoods become more attractive investors can reap higher returns. The idea behind it might be that investors use low interest rates to buy more properties. Also their initial purchases prices are lower than they would be in more saturated markets. Interestingly, those increases in prices in lower income neighborhood may positively affect house prices of borrowers

\footnotetext{
${ }^{13}$ We normalize to use the monthly schedule.
} 
whose property is underwater. They may be able to refinance their loans at a lower rate, decreasing the probability of default. In the end, both effects are at play in the investor-heavy neighborhoods: renters wanting to become owners cannot afford as many homes as they previously could, but current homeowners benefit from the appreciation of their homes due to investors' presence. That being said, if a substantial number of investors were to sell their properties in bulk, these home prices may drop back down to normal levels.

A strong insight of this paper is the fact that smaller sized investors tend to invest in more localized neighborhoods around their headquarters. This strategy seems to provide strong returns, but at the price of a lower diversification, leading to smaller returns overall in both renovated and non-renovated homes. This implies that local governments may be able to stimulate housing prices by providing smaller-sized investors tax breaks or other incentives to locate to their communities. It means that one of the solutions to the affordability problem is a mix of investor buying with only a small footprint in the neighborhoods, to avoid a larger increase in prices.

\section{Conclusion}

In this paper we provide some results that deepen our understanding of the buying and selling behavior of investors, differentiating them into institutional and non-institutional investors to better understand their impact on the community in terms of affordability. We find that investors tend to invest in properties in lower income area, have larger returns (double their investments), and tend to increase home prices in neighborhoods by investing in them. This tends to lead to an increase in unaffordability of neighborhoods during times when incomes are mainly flat.

We also confirm that the increase of prices is also the result of investors' resale of properties, with a large number of properties on the market being sold between investors.

\section{Bibliography}

Barwick, P. J. and Pathak P. A. Forthcoming. The Costs of Free Entry: An Empirical Study of Real Estate Agents in Greater Boston. RAND Journal of Economics.

Bertaud, Alain. "Housing affordability in China: a stock and flow approach." Symposium on Low-income Housing in China, Beijing University, July. 2009.

Bracke, Philippe. "How long do housing cycles last? A duration analysis for 19 OECD countries." Journal of Housing Economics 22.3 (2013): 213-230.

Chen, Jie, Qianjin Hao, and Mark Stephens. "Assessing housing affordability in post-reform China: a case study of Shanghai." Housing Studies 25.6 (2010): 877-901. 
Haffner, Marietta, and Kristof Heylen. "User costs and housing expenses. Towards a more comprehensive approach to affordability." Housing Studies 26.04 (2011): 593-614.

Hancock, K.E. (1993). 'Can Pay? Won't Pay?' or Economic Principles of 'Affordability', Urban Studies, 30(1), 127-145.

Kutty, N. (2005). A New Measure of Housing Affordability: Estimates and Analytical Results. Housing Policy Debate, 16(1), 113-142.

Leishman, Chris, and Steven Rowley. "Affordable housing." The SAGE Handbook of Housing Studies (London: Sage) (2012): 379-396.

Maclennan, D., \& Williams, R. (1990). Affordable housing in Britain and the United States. York: Joseph Rowntree Foundation.

Ndubueze, Okey. "Measuring housing affordability: A composite approach." Centre for Urban and Regional Studies, University of Birmingham (2007).

Stone, Michael E. "What is housing affordability? The case for the residual income approach." Housing policy debate 17.1 (2006): 151-184.

Thalmann, Philippe. "'House poor'or simply 'poor'?." Journal of Housing Economics 12.4 (2003): 291-317.

Stone, M. E. (2006). What is Housing Affordability? The Case for the Residual Income Approach. Housing Policy Debate, 17(1), 151-184.

Stone, Michael E. "The residual income approach to housing affordability: the theory and the practice." (2011).

Yates, Judith, and Maryann Wulff. "Market provision of affordable rental housing: lessons from recent trends in Australia." Urban Policy and Research23.1 (2005): 5-19.

Ying, Qianwei, Danglun Luo, and Jie Chen. "The determinants of homeownership affordability among the 'sandwich class': empirical findings from Guangzhou, China." Urban Studies (2013): 0042098012470398. 


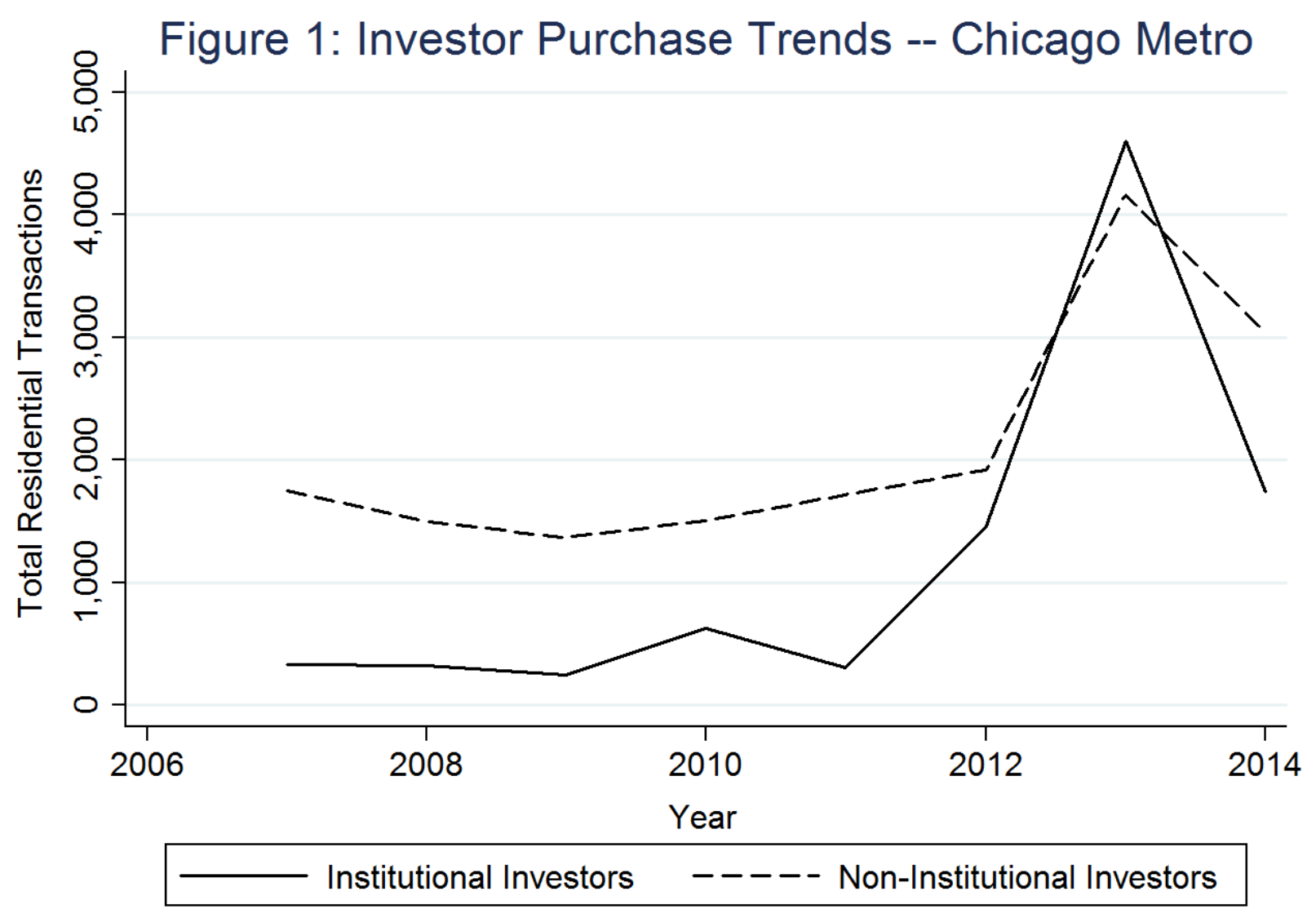




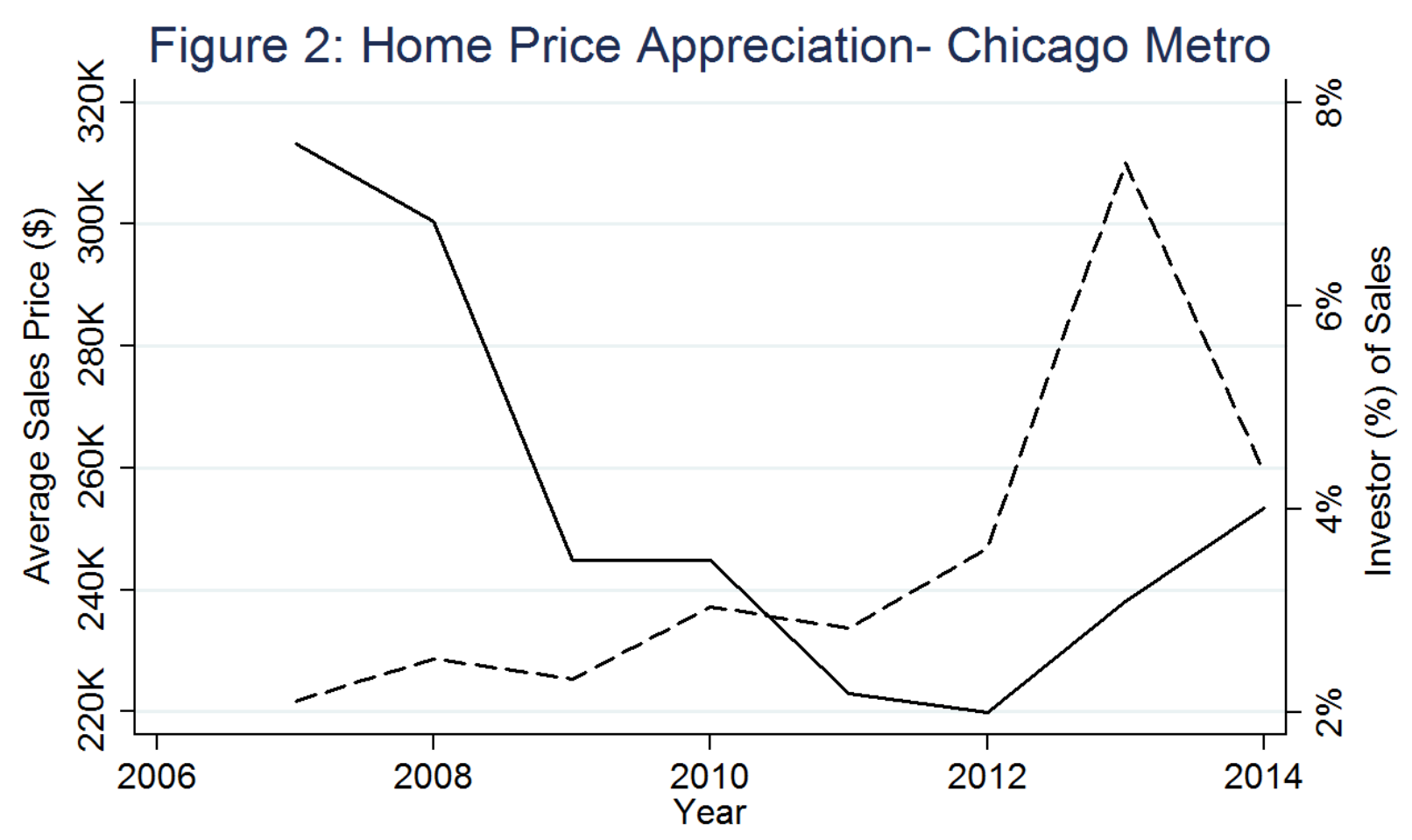

Average Sales Price $\quad$ - - - - Investor Percent of Sales

Home Price Appreciation coincides with rapid increase in Investor Activity 
Figure 3: Investors Flood Micro-Markets -- Chicago Metro

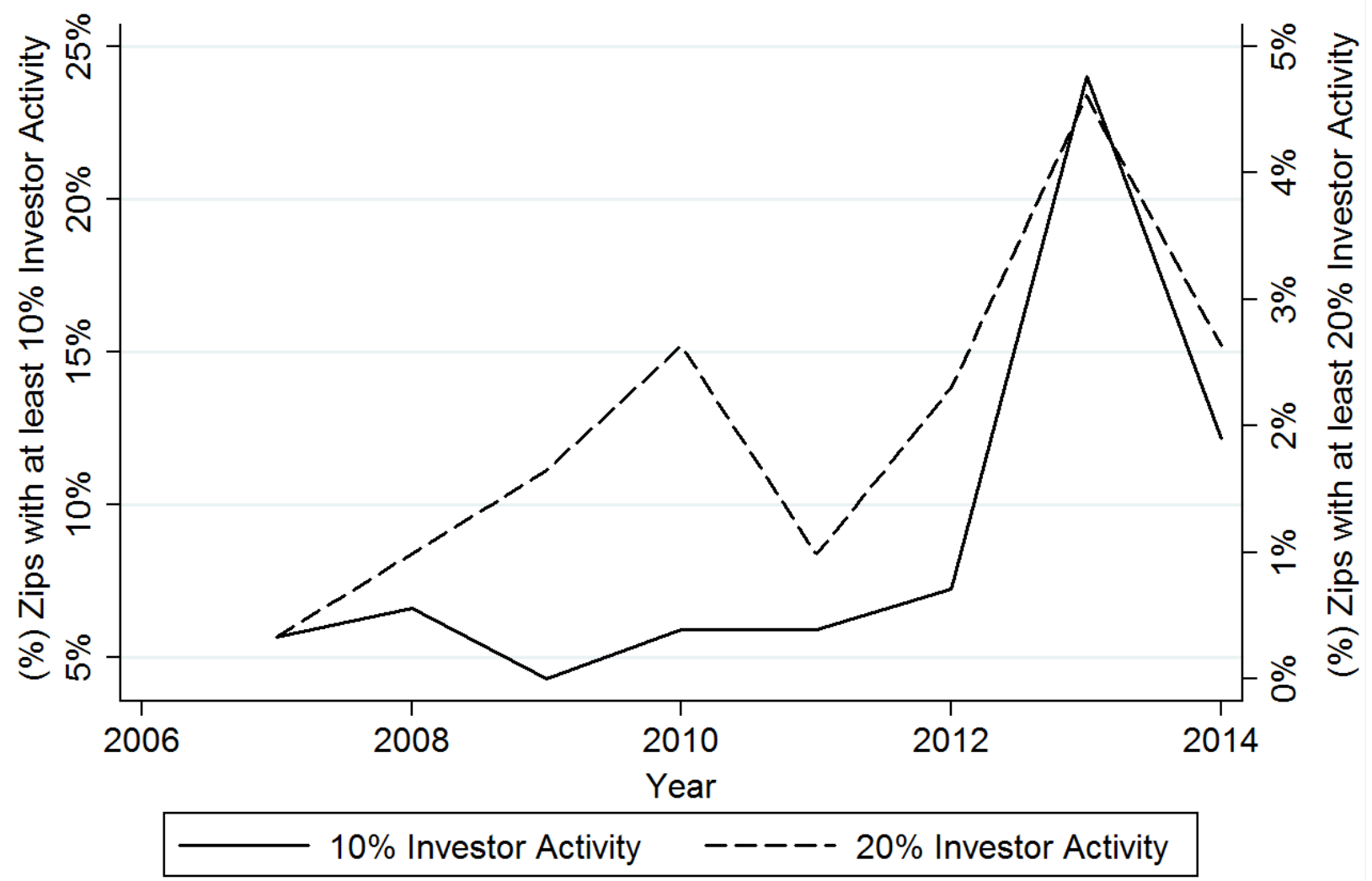



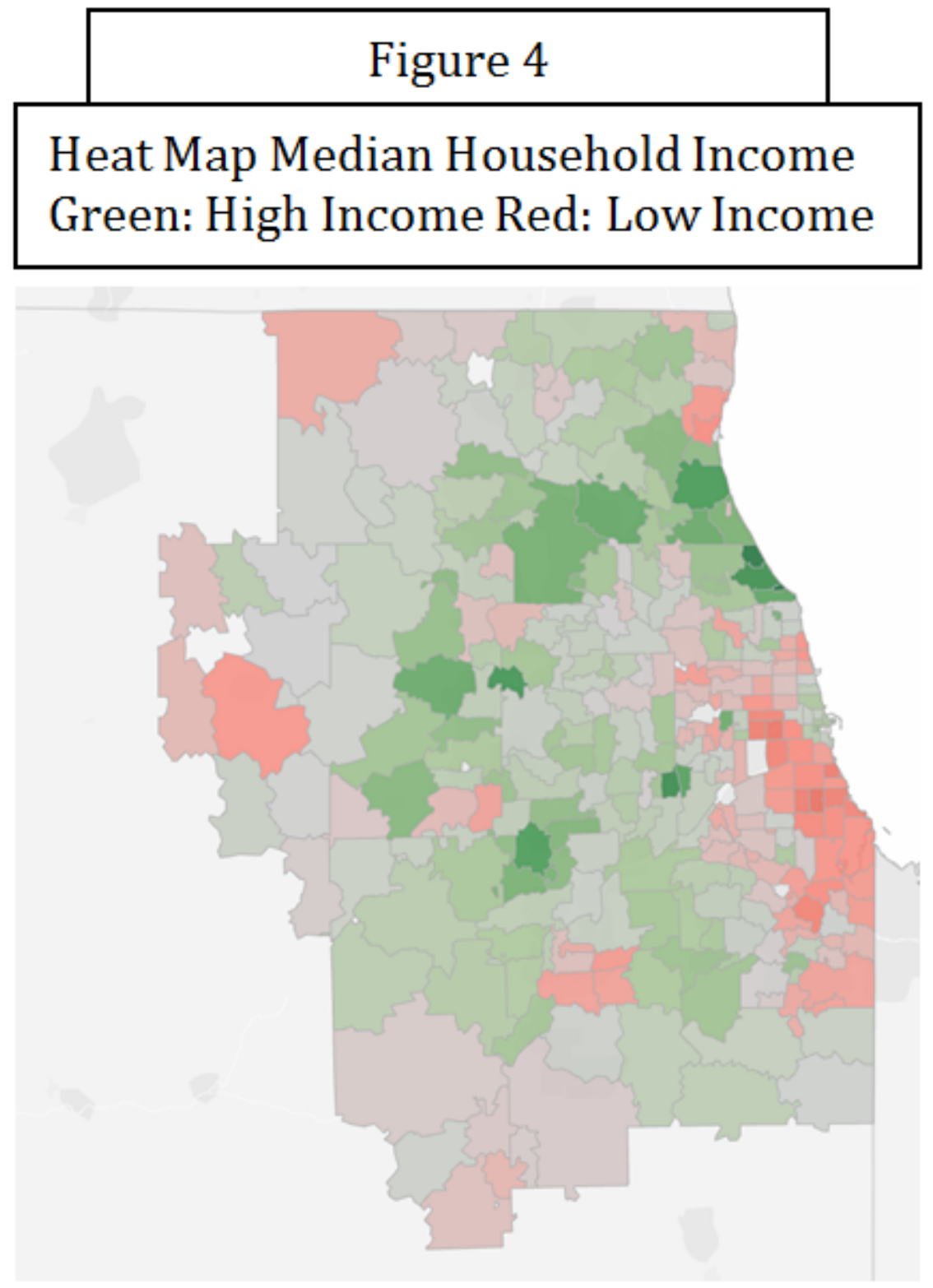
Figure 5

Heat Map (\%) Investor Activity Green: Low Activity Red: High Activity 
Figure 6: Red: High Investor Activity; Green: Low Investor Activity

Non Institutional Investors Institutional Investors (No Blackstone)

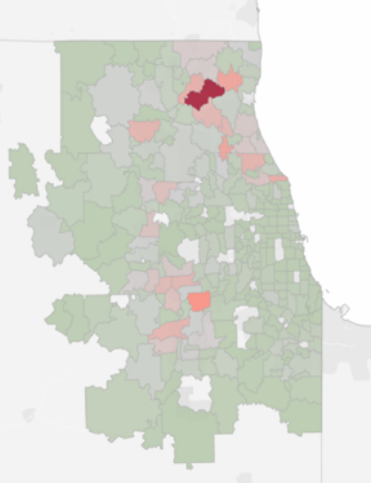

Blackstone

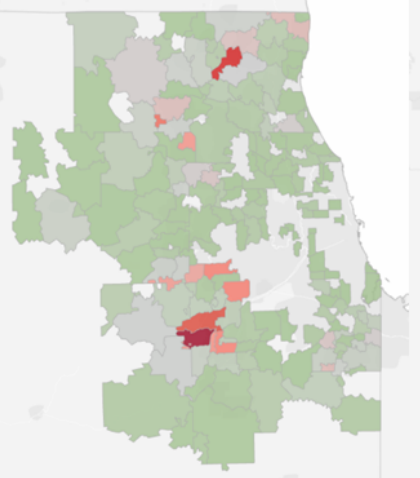

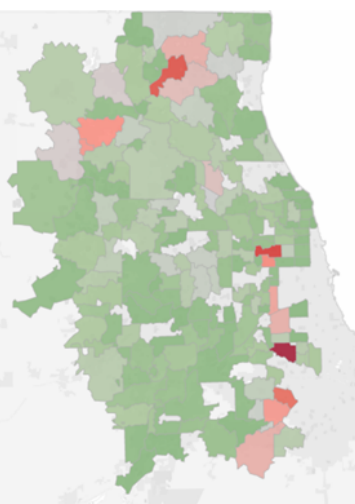


Table 1

State Offices of Institutional and Non-Institutional Investors Purchasing Properties Chicago Metro Area from 1/1/2007 to $3 / 31 / 2014$

\begin{tabular}{llrc} 
Type of Invester & Base Location & Total Properties & (\%) Overall \\
\hline & & & \\
Non-Institutional & Illinois & 13,034 & $88.8 \%$ \\
Non-Institutional & Out of Illinois & 1,643 & $11.2 \%$ \\
Non-Institutional & Total & 14,677 & \\
Institutional & Illinois & 4,950 & $59.7 \%$ \\
Institutional & Out of Illinois & 3,346 & $40.3 \%$ \\
Institutional & Total & 8,296 &
\end{tabular}

Table 2

Summary of Distances of Investor Properties From Headquarters Both Investor Properties and Headquarters Located in Chicago Metro

Miles From Hea
$\mathrm{x}<=5$
$5<\mathrm{x}<=10$
$10<\mathrm{x}<=15$
$15<\mathrm{x}<=20$
$20<\mathrm{x}<=25$
$25<\mathrm{x}<=30$
$30<\mathrm{x}<=35$
$35<\mathrm{x}<=40$
$40<\mathrm{x}<=45$
$45<\mathrm{x}<=50$
$50<\mathrm{x}<=75$
$\mathrm{x}>75$

Total

(\%) of Total
$49.6 \%$
$20.1 \%$
$10.9 \%$
$6.6 \%$
$4.4 \%$
$2.8 \%$
$1.8 \%$
$1.4 \%$
$1.0 \%$
$0.6 \%$
$0.8 \%$
$0.1 \%$

12741

$9.6 \%$

$10.9 \%$

$6.6 \%$

$4.4 \%$

$1.8 \%$

$1.4 \%$

$1.0 \%$
$0.6 \%$

$0.8 \%$

$1 \%$
Institutional Properties
(\%) of Total

$20.6 \%$

$13.9 \%$

$11.5 \%$

$9.3 \%$

$9.1 \%$

$10.2 \%$

$10.0 \%$

$7.0 \%$

$2.0 \%$

$0.8 \%$

$5.6 \%$

$0.0 \%$

Table 3

Matching Investor Data to MLS Sales in Chicago Metro Area

\begin{tabular}{|c|c|c|c|c|}
\hline Investor Type & Total Investor Purchases & MLS Observed Purchases & MLS Observed Sales & Matched Sales Purchase \\
\hline Non Institutional & 14,677 & 5,347 & 840 & 534 \\
\hline Institutional & 8,296 & 2,220 & 199 & 107 \\
\hline Both & 22,973 & 7,567 & 1039 & 641 \\
\hline
\end{tabular}


Table 4

Summarizing Selling Premium of Institutional vs. Non-Institutional Investors on Matched Sales

\begin{tabular}{lrrrr} 
Investor Type & Avergage Turnover (Days) & Average Sold Premium (\$) & Average Sold Premium (\%) & Pooled Sold Premium (\%) \\
\hline Non Institutional & 579 & 120,186 & $99.5 \%$ & $73.4 \%$ \\
Institutional & 721 & 112,537 & $104.8 \%$ & $93.0 \%$ \\
Both & 603 & 118,909 & $100.4 \%$ & $75.9 \%$
\end{tabular}

\title{
Table 5
}

Words Used to Identify Renovation in MLS Description

\author{
rehab \\ remodel \\ redone \\ renovation \\ renovate \\ redevelop \\ rebuilt \\ upgraded \\ updated \\ gut \\ construction
}

Table 6

Summary of Regular Sales vs. Renovated Sales

\begin{tabular}{lrrrr} 
Investor Type & Total Matched to MLS & Total With Renovation & Total With No Renovation & No Matched Comment \\
\hline Non Institutional & 534 & 321 & 61 & 152 \\
Institutional & 107 & 51 & 8 & 48 \\
Both & 641 & 372 & 69 & 200
\end{tabular}


Table 7

Summarizing Selling Premium of Institutional vs. Non-Institional Investors Stratified By Renovation

\begin{tabular}{|c|c|c|c|c|c|}
\hline Investor Type & Renovation & Avergage Turnover (Days) & Average Sold Premium (\$) & Average Sold Premium (\%) & Pooled Sold Premium (\%) \\
\hline Non Institutional & Yes & 321 & 133,119 & $110.0 \%$ & $89.3 \%$ \\
\hline Non Institutional & No & 1,026 & 32,070 & $31.0 \%$ & $11.6 \%$ \\
\hline Institutional & Yes & 438 & 138,814 & $127.1 \%$ & $109.3 \%$ \\
\hline Institutional & No & 1,409 & 72,318 & $71.9 \%$ & $72.2 \%$ \\
\hline Both & Yes & 483 & 133,900 & $112.4 \%$ & $91.7 \%$ \\
\hline Both & No & 1070 & 36,737 & $35.8 \%$ & $14.3 \%$ \\
\hline
\end{tabular}


Table 8: Regression on Price Sales - Measuring Investor Effects (Logged)

\begin{tabular}{lcccc}
\hline & $(1)$ & $(2)$ & $(3)$ & $(4)$ \\
\hline Investor Purchase $(=1)$ & $0.0466^{* * *}$ & $0.0485^{* * *}$ & $0.0509^{* * *}$ & $0.0638^{* * *}$ \\
& $(0.00827)$ & $(0.00799)$ & $(0.00797)$ & $(0.00781)$ \\
Local Community Controls & $\mathrm{X}$ & $\mathrm{X}$ & $\mathrm{X}$ & $\mathrm{X}$ \\
Property Characteristic Controls & $\mathrm{X}$ & $\mathrm{X}$ & $\mathrm{X}$ & $\mathrm{X}$ \\
Year Fixed Effect & $\mathrm{X}$ & $\mathrm{X}$ & $\mathrm{X}$ & $\mathrm{X}$ \\
Proximity to Downtown & & $\mathrm{X}$ & $\mathrm{X}$ & $\mathrm{X}$ \\
Auction & & & $\mathrm{X}$ & $\mathrm{X}$ \\
Investor Rate & & & & $\mathrm{X}$ \\
\hline Observations & & & & 263204 \\
$R^{2}$ & 287768 & 287768 & 287768 & 2607 \\
\hline
\end{tabular}

Standard errors in parentheses

${ }^{*} p<0.05,{ }^{* *} p<0.01,{ }^{* * *} p<0.001$ 
Table 9: Regression on Price Sales - Measuring Non-Institutional vs Investor Effects on Purchases and Sales (Logged)

\begin{tabular}{lcccc}
\hline & $(1)$ & $(2)$ & $(3)$ & $(4)$ \\
\hline Non-Institutional Sales (=1) & $0.262^{* * *}$ & $0.264^{* * *}$ & $0.257^{* * *}$ & $0.268^{* * *}$ \\
& $(0.0234)$ & $(0.0226)$ & $(0.0225)$ & $(0.0228)$ \\
Institutional Sales (=1) & $0.315^{* * *}$ & $0.328^{* * *}$ & $0.324^{* * *}$ & $0.343^{* * *}$ \\
& $(0.0459)$ & $(0.0443)$ & $(0.0442)$ & $(0.0436)$ \\
Non-Institutional Purchase (=1) & $0.0209^{*}$ & $0.0278^{* *}$ & $0.0322^{* * *}$ & $0.0477^{* * *}$ \\
& $(0.0101)$ & $(0.00980)$ & $(0.00977)$ & $(0.00957)$ \\
Institutional Purchase (=1) & $0.0980^{* * *}$ & $0.0902^{* * *}$ & $0.0888^{* * *}$ & $0.0965^{* * *}$ \\
& $(0.0140)$ & $(0.0135)$ & $(0.0135)$ & $(0.0132)$ \\
Local Community Controls & $\mathrm{X}$ & $\mathrm{X}$ & $\mathrm{X}$ & $\mathrm{X}$ \\
Property Characteristic Controls & $\mathrm{X}$ & $\mathrm{X}$ & $\mathrm{X}$ & $\mathrm{X}$ \\
Year Fixed Effect & $\mathrm{X}$ & $\mathrm{X}$ & $\mathrm{X}$ & $\mathrm{X}$ \\
Proximity to Downtown & & $\mathrm{X}$ & $\mathrm{X}$ & $\mathrm{X}$ \\
Auction & & & $\mathrm{X}$ & $\mathrm{X}$ \\
Investor Rate & & & & $\mathrm{X}$ \\
\hline Observations & 287768 & 287768 & 287768 & 263204 \\
$R^{2}$ & 0.6681 & 0.6905 & 0.6920 & 0.7007 \\
\hline
\end{tabular}

Standard errors in parentheses

${ }^{*} p<0.05,{ }^{* *} p<0.01,{ }^{* * *} p<0.001$ 
Table 10: Regression on Investor Purchase Price (Logged)

\begin{tabular}{lccc}
\hline & $(1)$ & $(2)$ & $(3)$ \\
\hline Portfolio Count (logged) & $0.0294^{* * *}$ & $0.0280^{* * *}$ & $0.0280^{* * *}$ \\
& $(0.00530)$ & $(0.00516)$ & $(0.00516)$ \\
Institutional Investors (=1) & $-0.0977^{* * *}$ & $-0.0880^{* *}$ & $-0.0822^{* *}$ \\
& $(0.0282)$ & $(0.0275)$ & $(0.0275)$ \\
Within 5 Miles of HQ $(=1)$ & $0.0892^{* * *}$ & $0.0797^{* * *}$ & $0.0806^{* * *}$ \\
& $(0.0133)$ & $(0.0129)$ & $(0.0129)$ \\
Headquarters In State $(=1)$ & $-0.0602^{* *}$ & $-0.0717^{* * *}$ & $-0.0726^{* * *}$ \\
& $(0.0203)$ & $(0.0198)$ & $(0.0197)$ \\
Bought At Auction (=1) & $-0.311^{* * *}$ & $-0.296^{* * *}$ & $-0.297^{* * *}$ \\
& $(0.0483)$ & $(0.0470)$ & $(0.0470)$ \\
Local Community Controls & $\mathrm{X}$ & $\mathrm{X}$ & $\mathrm{X}$ \\
Property Characteristic Controls & $\mathrm{X}$ & $\mathrm{X}$ & $\mathrm{X}$ \\
Year Fixed Effects & $\mathrm{X}$ & $\mathrm{X}$ & $\mathrm{X}$ \\
Proximity to Downtown & & $\mathrm{X}$ & $\mathrm{X}$ \\
Investor Rate & & & $\mathrm{X}$ \\
\hline Observations & 4430 & 4430 & 4421 \\
$R^{2}$ & 0.6624 & 0.6803 & 0.6813 \\
\hline Stangar & & & \\
\hline
\end{tabular}

Standard errors in parentheses

${ }^{*} p<0.05,{ }^{* *} p<0.01,{ }^{* * *} p<0.001$ 
Table 11: Regression on Investor Re-Sale Premium (Logged)

\begin{tabular}{lcc}
\hline & $(1)$ & $(2)$ \\
\hline Foreclosure Rate (logged) & $0.150^{* * *}$ & $0.300^{* * *}$ \\
& $(0.0340)$ & $(0.0377)$ \\
Median Income (logged) & $-0.373^{* * *}$ & -0.137 \\
& $(0.0922)$ & $(0.0944)$ \\
School Percentile (logged) & $-0.226^{* * *}$ & $-0.180^{* * *}$ \\
& $(0.0443)$ & $(0.0437)$ \\
Vacancy Rate (logged) & $-0.116^{* * *}$ & $-0.120^{* * *}$ \\
& $(0.0203)$ & $(0.0199)$ \\
In Chicago (=1) & $-1.172^{* * *}$ & $-0.988^{* * *}$ \\
& $(0.0870)$ & $(0.0880)$ \\
Year Fixed Effects & $\mathrm{X}$ & $\mathrm{X}$ \\
Turnover Rate (logged) & & $\mathrm{X}$ \\
\hline Observations & 1668 & 1668 \\
$R^{2}$ & 0.2566 & 0.2876 \\
\hline Stan
\end{tabular}

Standard errors in parentheses

${ }^{*} p<0.05,{ }^{* *} p<0.01,{ }^{* * *} p<0.001$ 
Table 12: Regression on Sales Price of Properties One Mile Nearby Investor Cluster (Logged)

\begin{tabular}{lccc}
\hline & $(1)$ & $(2)$ & $(3)$ \\
\hline Within Cluster $(=1)$ & $-0.0215^{*}$ & 0.0166 & 0.0153 \\
& $(0.00925)$ & $(0.00894)$ & $(0.00891)$ \\
One Year After Cluster $(=1)$ & $0.0490^{* *}$ & $0.0504^{* *}$ & $0.0531^{* *}$ \\
& $(0.0186)$ & $(0.0180)$ & $(0.0179)$ \\
Local Community Controls & $\mathrm{X}$ & $\mathrm{X}$ & $\mathrm{X}$ \\
Property Characteristic Controls & $\mathrm{X}$ & $\mathrm{X}$ & $\mathrm{X}$ \\
Year Fixed Effect & $\mathrm{X}$ & $\mathrm{X}$ & $\mathrm{X}$ \\
Distance From Downtown & & $\mathrm{X}$ & $\mathrm{X}$ \\
Auction & & & $\mathrm{X}$ \\
\hline Observations & & & 225497 \\
$R^{2}$ & 225497 & 225497 & 0.6922 \\
\hline
\end{tabular}

Standard errors in parentheses

${ }^{*} p<0.05,{ }^{* *} p<0.01,{ }^{* * *} p<0.001$ 
Table 13: Regression on (\%) Investor Activity Per Zip (Logged)

\begin{tabular}{lcc}
\hline & $(1)$ & $(2)$ \\
\hline Foreclosure Rate (logged) & $0.150^{* * *}$ & $0.300^{* * *}$ \\
& $(0.0340)$ & $(0.0377)$ \\
Median Income (logged) & $-0.373^{* * *}$ & -0.137 \\
& $(0.0922)$ & $(0.0944)$ \\
School Percentile (logged) & $-0.226^{* * *}$ & $-0.180^{* * *}$ \\
& $(0.0443)$ & $(0.0437)$ \\
Vacancy Rate (logged) & $-0.116^{* * *}$ & $-0.120^{* * *}$ \\
& $(0.0203)$ & $(0.0199)$ \\
In Chicago (=1) & $-1.172^{* * *}$ & $-0.988^{* * *}$ \\
& $(0.0870)$ & $(0.0880)$ \\
Year Fixed Effects & $\mathrm{X}$ & $\mathrm{X}$ \\
Turnover Rate (logged) & & $\mathrm{X}$ \\
\hline Observations & 1668 & 1668 \\
$R^{2}$ & 0.2566 & 0.2876 \\
\hline
\end{tabular}

Standard errors in parentheses

${ }^{*} p<0.05,{ }^{* *} p<0.01,{ }^{* * *} p<0.001$ 
Table 14: Regression on Renter Affordability, 20\% Income (Logged)

\begin{tabular}{lcccc}
\hline \hline Blackstone & $-0.200^{* * *}$ & $-0.203^{* * *}$ & $-0.196^{* * *}$ & $-0.186^{* * *}$ \\
& $(0.0144)$ & $(0.0144)$ & $(0.0165)$ & $(0.0166)$ \\
Local Community Controls & $\mathrm{X}$ & $\mathrm{X}$ & $\mathrm{X}$ & $\mathrm{X}$ \\
Property Controls & $\mathrm{X}$ & $\mathrm{X}$ & $\mathrm{X}$ & $\mathrm{X}$ \\
Year Controls & $\mathrm{X}$ & $\mathrm{X}$ & $\mathrm{X}$ & $\mathrm{X}$ \\
Days on Market (logged) & & $\mathrm{X}$ & $\mathrm{X}$ & $\mathrm{X}$ \\
Inst (=1) & & & $\mathrm{X}$ & $\mathrm{X}$ \\
Investor Prop (logged) & & & & $\mathrm{X}$ \\
\hline Observations & 5496 & 5448 & 5448 & 5338 \\
$R^{2}$ & 0.5266 & 0.5267 & 0.5268 & 0.5289 \\
\hline
\end{tabular}

Standard errors in parentheses

${ }^{*} p<0.05,{ }^{* *} p<0.01,{ }^{* * *} p<0.001$ 
Table 15: Regression on Renter Affordability, 30\% Income (Logged)

\begin{tabular}{lcccc}
\hline \hline Blackstone & $-0.163^{* * *}$ & $-0.165^{* * *}$ & $-0.170^{* * *}$ & $-0.163^{* * *}$ \\
& $(0.0120)$ & $(0.0121)$ & $(0.0139)$ & $(0.0140)$ \\
Local Community Controls & $\mathrm{X}$ & $\mathrm{X}$ & $\mathrm{X}$ & $\mathrm{X}$ \\
Property Controls & $\mathrm{X}$ & $\mathrm{X}$ & $\mathrm{X}$ & $\mathrm{X}$ \\
Year Controls & $\mathrm{X}$ & $\mathrm{X}$ & $\mathrm{X}$ & $\mathrm{X}$ \\
Days on Market (logged) & & $\mathrm{X}$ & $\mathrm{X}$ & $\mathrm{X}$ \\
Inst $(=1)$ & & & $\mathrm{X}$ & $\mathrm{X}$ \\
Investor Prop (logged) & & & & $\mathrm{X}$ \\
\hline Observations & 5551 & 5503 & 5503 & 5390 \\
$R^{2}$ & 0.5082 & 0.5081 & 0.5082 & 0.5079 \\
\hline Standard errors in parentheses & & & & \\
$* p<0.05,{ }^{* *} p<0.01,{ }^{* * *} p<0.001$ & & & &
\end{tabular}

Table 16: Regression on Renter Affordability, 40\% Income (Logged)

\begin{tabular}{lcccc}
\hline \hline Blackstone & $-0.0846^{* * *}$ & $-0.0853^{* * *}$ & $-0.0942^{* * *}$ & $-0.0930^{* * *}$ \\
& $(0.00908)$ & $(0.00914)$ & $(0.0105)$ & $(0.0106)$ \\
Local Community Controls & $\mathrm{X}$ & $\mathrm{X}$ & $\mathrm{X}$ & $\mathrm{X}$ \\
Property Controls & $\mathrm{X}$ & $\mathrm{X}$ & $\mathrm{X}$ & $\mathrm{X}$ \\
Year Controls & $\mathrm{X}$ & $\mathrm{X}$ & $\mathrm{X}$ & $\mathrm{X}$ \\
Days on Market (logged) & & $\mathrm{X}$ & $\mathrm{X}$ & $\mathrm{X}$ \\
Inst (=1) & & & $\mathrm{X}$ & $\mathrm{X}$ \\
Investor Prop (logged) & & & & $\mathrm{X}$ \\
\hline Observations & 5590 & 5541 & 5541 & 5426 \\
$R^{2}$ & 0.4815 & 0.4818 & 0.4820 & 0.4795 \\
\hline
\end{tabular}

Standard errors in parentheses

${ }^{*} p<0.05,{ }^{* *} p<0.01,{ }^{* * *} p<0.001$ 
Table 17: Regression on Renter Affordability, Stratified by Affordability Threshold (Logged)

\begin{tabular}{lccc}
\hline & $(1)$ & $(2)$ & $(3)$ \\
& $20 \%$ & $30 \%$ & $40 \%$ \\
\hline Blackstone & $-0.186^{* * *}$ & $-0.163^{* * *}$ & $-0.0930^{* * *}$ \\
& $(0.0166)$ & $(0.0140)$ & $(0.0106)$ \\
Local Community Controls & $\mathrm{X}$ & $\mathrm{X}$ & $\mathrm{X}$ \\
Property Controls & $\mathrm{X}$ & $\mathrm{X}$ & $\mathrm{X}$ \\
Year Controls & $\mathrm{X}$ & $\mathrm{X}$ & $\mathrm{X}$ \\
Days on Market (logged) & $\mathrm{X}$ & $\mathrm{X}$ & $\mathrm{X}$ \\
Inst (=1) & $\mathrm{X}$ & $\mathrm{X}$ & $\mathrm{X}$ \\
Investor Prop (logged) & $\mathrm{X}$ & $\mathrm{X}$ & $\mathrm{X}$ \\
\hline Observations & 5338 & 5390 & 5426 \\
$R^{2}$ & 0.5289 & 0.5079 & 0.4795 \\
\hline
\end{tabular}

Standard errors in parentheses

${ }^{*} p<0.05,{ }^{* *} p<0.01,{ }^{* * *} p<0.001$

Table 18

Rent Yields - Home Price Normalized Using FHFA Metro Index

\begin{tabular}{lrrrr} 
Investor Type & Total Observations & Average Adjusted Acquisition Price & Average Rent & Average Days on Market \\
\hline Non Institutional & 5,859 & 303,682 & 1,685 & 51.4 \\
Institutional (Non-Blackstone) & 1,643 & 252,337 & 1,637 & 51.9 \\
Blackstone & 1,574 & 190,606 & 1,890 & 52.0 \\
Total & 9,076 & 274,777 & 1,712
\end{tabular}

Table 19

Rent Yields - Home Price Normalized Using Zip Code Transactions

\begin{tabular}{lrrrr} 
Investor Type & Total Observations & Average Adjusted Acquisition Price & Average Rent & Average Days on Market \\
\hline Non Institutional & 2,785 & 177,888 & 1,662 & 47.4 \\
Institutional (Non- Blackstone) & 1,348 & 149,532 & 1,662 & 1,891 \\
Blackstone & 1,568 & 192,538 & 48.8 \\
Total & 5,701 & 175,213 & 1,725 & 52.0
\end{tabular}


Table 20

Characterisitcs of Mortgages Used to Purchase Investor-Sold Properties

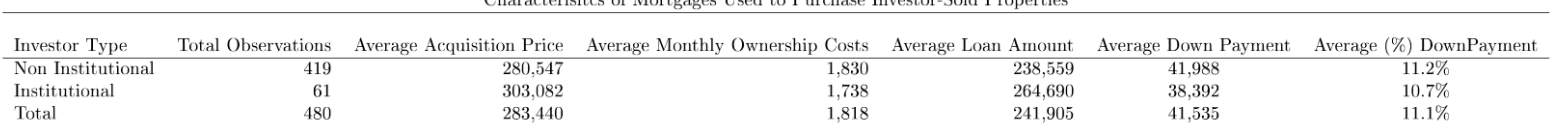

Table 21

Categories of Loans Used to Purchase Investor Homes (\% of Overall Transactions)

\begin{tabular}{lrrrr} 
Investor Type & FHA Loan & VA Loan & Conventional Loan & Private Loan \\
\hline Non Institutional & $36.1 \%$ & $7.0 \%$ & $56.0 \%$ & $1.0 \%$ \\
Institutional & $26.3 \%$ & $3.5 \%$ & $68.4 \%$ & $1.8 \%$ \\
Total & $34.9 \%$ & $6.5 \%$ & $57.5 \%$ & $1.1 \%$
\end{tabular}

Table 22

\begin{tabular}{lrr}
\multicolumn{3}{c}{ National Share of FHA Loan (\% of Total Purchase) } \\
\hline & & \\
Time Period & FHA Loan & Average Interest Rate (Fixed, 30 Yr) \\
\hline 2014 Q4 & $21.6 \%$ & $3.97 \%$ \\
2014 Q3 & $22.1 \%$ & $4.14 \%$ \\
2014 Q2 & $21.7 \%$ & $4.23 \%$ \\
2014 Q1 & $23.6 \%$ & $4.36 \%$
\end{tabular}


Table 23

Types of Mortgages Used to Purchase Investor Sold Homes

\begin{tabular}{lccc} 
Investor Type & Fixed Rate & Adjustable Rate & Average Rate \\
\hline Non Institutional & $87.2 \%$ & $12.8 \%$ & $4.22 \%$ \\
Institutional & $77.4 \%$ & $22.6 \%$ & $4.24 \%$ \\
Total & $86.0 \%$ & $14.0 \%$ & $4.22 \%$
\end{tabular}

Table 24

Number of Mortgages Used to Purchase Investor Sold Homes

\begin{tabular}{lcc} 
Investor Type & One Loan & More than One Loan \\
\hline Non Institutional & $92.5 \%$ & $7.5 \%$ \\
Institutional & $93.8 \%$ & $6.2 \%$ \\
Total & $92.7 \%$ & $7.3 \%$
\end{tabular}

Table 25

Summary of Average Down Payment on Investor Sold Properties Stratified by the Purchase Price

\begin{tabular}{|c|c|c|c|c|}
\hline Purchae Price & Non-Institutional Average Down Payment & (\%) of Total Observations & Institutional Average Down Payment & (\%) of Total Observations \\
\hline $\mathrm{x}<=100,000$ & $4.46 \%$ & $1.19 \%$ & $8.58 \%$ & $8.20 \%$ \\
\hline $100,000<\mathrm{x}<=150,000$ & $7.30 \%$ & $16.47 \%$ & $10.90 \%$ & $9.84 \%$ \\
\hline $150,000<\mathrm{x}<=200,000$ & $4.90 \%$ & $26.01 \%$ & $8.59 \%$ & $8.20 \%$ \\
\hline $200,000<\mathrm{x}<=250,000$ & $10.44 \%$ & $16.71 \%$ & $5.86 \%$ & $9.84 \%$ \\
\hline $250,000<\mathrm{x}<=300,000$ & $16.00 \%$ & $10.74 \%$ & $3.84 \%$ & $21.31 \%$ \\
\hline $300,000<\mathrm{x}<=400,000$ & $11.43 \%$ & $13.84 \%$ & $9.96 \%$ & $14.75 \%$ \\
\hline $400,000<\mathrm{x}<=500.000$ & $18.80 \%$ & $5.01 \%$ & $18.01 \%$ & $18.03 \%$ \\
\hline $500,000<\mathrm{x}<=750,000$ & $28.17 \%$ & $5.73 \%$ & $21.53 \%$ & $9.84 \%$ \\
\hline$x>750,000$ & $25.11 \%$ & $4.30 \%$ & $\mathrm{~N} / \mathrm{A}$ & $0 \%$ \\
\hline Total & $11.20 \%$ & & $10.70 \%$ & \\
\hline
\end{tabular}


Table 26

\title{
Words Used to Identify Investors in Individuals Purchasing Homes From Investors
}

\author{
LLC \\ Trust \\ Inc \\ Company \\ Fund \\ Invest \\ Community \\ Bank
}

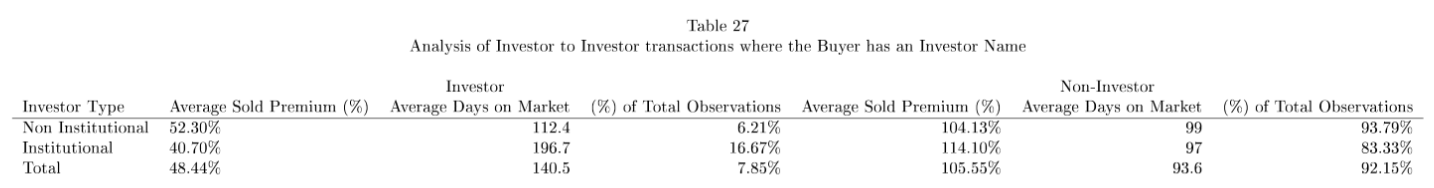

Table 28

Analysis of Investor to Investor transactions where the Buyer was Cash Buyer (e.g. No Mortgage)

\begin{tabular}{|c|c|c|c|c|c|c|}
\hline Inyestor Type & Average Sold Premiuu (\%) & $\begin{array}{c}\text { Investor } \\
\text { Ayerage Davs }\end{array}$ & (\%) of Total Observations & Average Sold Premium (\%) & $\begin{array}{l}\text { Non-Investor } \\
\text { Average }\end{array}$ & (\%) of Total Observations \\
\hline Non Institutional & $58.23 \%$ & 83.4 & $11.62 \%$ & $106.93 \%$ & 95.1 & $88.38 \%$ \\
\hline Institutional & $26.54 \%$ & 152.5 & $26.97 \%$ & $129.31 \%$ & 99.8 & $73.03 \%$ \\
\hline Total & $48.73 \%$ & 104.1 & $14.01 \%$ & $109.90 \%$ & 95.7 & $85.99 \%$ \\
\hline
\end{tabular}


Table 29

Percentile Rank of Home Within Micro Community

\begin{tabular}{lcc} 
Investor Type & At Purchase & When Sold \\
\hline Non Institutional & $38 \%$ & $70 \%$ \\
Institutional & $34 \%$ & $70 \%$ \\
Total & $37 \%$ & $70 \%$
\end{tabular}

Table 30

(\%) Of the Community that Can Afford the Home Stratified by Different Income Limits

\begin{tabular}{lllll} 
Investor Type & $20 \%$ & $30 \%$ & $40 \%$ & $50 \%$ \\
\hline Non Institutional & $37 \%$ & $54 \%$ & $64 \%$ & $71 \%$ \\
Institutional & $39 \%$ & $54 \%$ & $65 \%$ & $72 \%$ \\
Total & $37 \%$ & $54 \%$ & $64 \%$ & $71 \%$
\end{tabular}


Table 31: Probit Regression on Likelihood of Investor to Investor Activity (Logged)

\begin{tabular}{|c|c|}
\hline Multiple Properties & $\begin{array}{l}-0.876^{* *} \\
(0.3337)\end{array}$ \\
\hline Affordable Property (logged) & $\begin{array}{l}1.626^{* * *} \\
(0.4734)\end{array}$ \\
\hline Portfolio Size & $\begin{array}{c}0.550^{* * *} \\
(0.1374)\end{array}$ \\
\hline School Percentile (logged) & $\begin{array}{c}-0.832^{* *} \\
(0.2657)\end{array}$ \\
\hline Local Community Controls & $\mathrm{X}$ \\
\hline Property Controls & $\mathrm{X}$ \\
\hline Days on Market (logged) & $\mathrm{X}$ \\
\hline Observations & 5496 \\
\hline PseudoR $^{2}$ & 0.5266 \\
\hline
\end{tabular}


Table 32: Regression on Mortgage Affordability, Institutional Investor Effect (Logged)

\begin{tabular}{lccc}
\hline & $(1)$ & $(2)$ & $(3)$ \\
& $20 \%$ & $30 \%$ & $40 \%$ \\
\hline Institutional & $-0.074^{*}$ & $-0.076^{*}$ & $-0.069^{*}$ \\
& $(0.0370)$ & $(0.0342)$ & $(0.0302)$ \\
Remodel & $\mathrm{X}$ & $\mathrm{X}$ & $\mathrm{X}$ \\
Investor Location Controls & $\mathrm{X}$ & $\mathrm{X}$ & $\mathrm{X}$ \\
Local Community Controls & $\mathrm{X}$ & $\mathrm{X}$ & $\mathrm{X}$ \\
Property Controls & $\mathrm{X}$ & $\mathrm{X}$ & $\mathrm{X}$ \\
Days on Market (logged) & $\mathrm{X}$ & $\mathrm{X}$ & $\mathrm{X}$ \\
\hline Observations & 231 & 241 & 243 \\
$R^{2}$ & 0.6611 & 0.6928 & 0.7121 \\
\hline
\end{tabular}

Standard errors in parentheses

${ }^{*} p<0.05,{ }^{* *} p<0.01,{ }^{* * *} p<0.001$ 
Readers with comments may address them to:

Professor Sebastien Gay sgay@uchicago.edu 


\section{The University of Chicago Law School Kreisman Working Papers on Housing Law and Policy}

For a listing of papers, please go to http://chicagounbound.uchicago.edu/housing_law_and_policy_wp/.

1. Lee Anne Fennell and Eduardo M. Peñalver, Exactions Creep, December 2013

2. $\quad$ Lee Anne Fennell, Forcings, November 2013

3. Neil Bhutta and Benjamin J. Keys, Interest Rates and Equity Extraction during the Housing Boom, January 2014

4. Christopher Mayer, Edward Morrison, Tomasz Piskorski, and Arpit Gupta, Mortgage Modification and Strategic Behavior: Evidence from a Legal Settlement with Countrywide, January 2014

5. $\quad$ Edward R. Morrison, Coasean Bargaining in Consumer Bankruptcy, January 2014

6. Atif Mian, Amir Sufi, and Francesco Trebbi, Foreclosures, House Prices, and the Real Economy, January 2014

7. Sumit Agarwal, Gene Amromin, Itzhak Ben-David, Souphala Chomsisengphet, Tomasz Piskorski, and Amit Seru, Policy Intervention in Debt Renegotiation: Evidence from the Home Affordable Modification Program, August 2012

8. Sumit Agarwal, Effi Benmelech, Nittai Bergman, and Amit Seru, Did the Community Reinvestment Act (CRA) Lead to Risky Lending? November 2012

9. Tomasz Piskorski, Amit Seru, and James Witkin, Asset Quality Misrepresentation by Financial Intermediaries: Evidence from RMBS Market, February 2013

10. Umit G. Gurun, Gregor Matvos, and Amit Seru, Advertising Expensive Mortgages, March 2013

11. Benjamin J. Keys, Devin G. Pope, and Jaren C. Pope, Failure to Refinance, August 2014

12. Adam B. Badawi and Anthony J. Casey, The Fannie and Freddie Bailouts through the Corporate Lens, March 2014

13. Lee Anne Fennell, Property in Housing, March 2013

14. Lee Anne Fennell, Just Enough, August 2013

15. Yun-chien Chang and Lee Anne Fennell, Partition and Revelation, April 2014

16. Robert J. Chaskin and Mark L. Joseph, Contested Space: Design Principles and Regulatory Regimes in Mixed-Income Communities Replacing Public Housing Complexes in Chicago, October 2014

17. Lee Anne Fennell, Agglomerama, December 2014

18. Sebastien Gay and Nadia Nasser-Ghodsi, Guarding the Subjective Premium: Condemnation Risk Discounts in the Housing Market, December 2014

19. Brian A. Jacob, Max Kapustin, and Jens Ludwig, Human Capital Effects of Anti-Poverty Programs: Evidence from a Randomized Housing Voucher Lottery, December 2014

20. Sebastien Gay and Allen T. Zhang, Expertise Value Added in the Real Estate Market, December 2014

21. Atif R. Mian and Amir Sufi, Fraudulent Income Overstatement on Mortgage Applications during the Credit Expansion of 2002 to 2005, February 2015

22. Sebastien Gay, Investors Effect on Household Real Estate Affordability, May 2015 